\title{
Proline iminopeptidase gene from Xanthomonas campestris pv. citri
}

\author{
Jorge Alonso and José L. García \\ Author for correspondence: José L. García. Tel: +34 15611800. Fax: +34 15627518. \\ e-mail: CIBJL16@PINAR1.CSIC.ES
}

Departamento de

Microbiología Molecular,

Centro de Investigaciones

Biológicas, Consejo

Superior de

Investigaciones Científicas,

Velázquez 144, 28006

Madrid, Spain
The pip gene coding for the proline iminopeptidase (Pip) of Xanthomonas campestris pv. citri was cloned in an Escherichia coli leuB strain using a selective medium containing the dipeptide D-Ala-L-Leu as the sole source of Lleucine. Nucleotide sequencing of this gene revealed a 939 bp open reading frame encoding a 312 amino acid protein ( $35126 \mathrm{Da}$ ). The deduced amino acid sequence showed $47 \%$ identity with the Pip from Neisseria gonorrhoeae. A lacZ-pip fusion gene was overexpressed in E. coli under the control of the Plac promoter. The Pip of $X$. campestris hydrolysed L-prolyl-p-nitroanilide with the highest efficiency, but was also able to hydrolyse L-alanyl-p-nitroanilide and Dalanyl-p-nitroanilide. The molecular mass of Pip was found to be $35 \mathrm{kDa}$ by SDS-PAGE and $120 \mathrm{kDa}$ by gel filtration, suggesting that the active enzyme is a multimer.

Keywords: Xanthomonas campestris pv. citri, proline iminopeptidase, D-alanine

\section{INTRODUCTION}

Xanthomonas campestris is a Gram-negative phytopathogenic bacterium belonging to the family Pseudomonadaceae. X. campestris pv. citri is associated with various citrus bacterial diseases (Verniere et al., 1993). Many factors are known to influence the pathogen-plant interaction, and it has been suggested that proteases of phytopathogenic bacteria have a role in disease development (Dow et al., 1993). Protease-deficient mutants of $X$. campestris pathovars induced only mild symptoms and showed reduced bacterial counts in plants (Dow et al., 1993).

Proline iminopeptidase (Pip, EC 3.4.11.5) was reported for the first time by Sarid et al. (1959). This enzyme has been found mainly in bacteria (Albertson \& Koomey, 1993; Allaker et al., 1994; Atlan et al., 1994; Ehrenfreund et al., 1992; Gilbert et al., 1994; Kitazono et al.,1994a, b; Klein et al., 1994; Yoshimoto et al., 1983) and, to a far lesser extent, in some plants (Ninomiya et al., 1982). Although an activity that cleaves the $\mathrm{N}$-terminal proline of certain proteins has been reported in some mammalian tissues (Hiraoka \& Harada, 1991), the presence of a real Pip remains uncertain. Furthermore, some mammalian aminopeptidases, such as leucine aminopeptidases and

Abbreviations: p-NA, p-nitroanilide; Pip, proline iminopeptidase. The GenBank accession number for the nucleotide sequence reported in this paper is Z54150. carboxylesterases, have a weak activity on the amide substrates used in the Pip assay (Kitazono et al., 1992).

This paper reports the cloning, sequencing and expression in Escherichia coli of the pip gene from X. campestris. Efforts to improve the expression level of this gene, and the characterization of the expressed enzyme, are also described.

\section{METHODS}

Bacterial strains, plasmids and media. $X$. campestris pv. citri IFO 3835 (Kato et al., 1980a) was provided by the Colección Española de Cultivos Tipo (CECT). E. coli strains used were: HB101 [F- pro A2 leuB supE44 ara-14 galK2 lac Y1 $\Delta(m c r C-m r r K)$ rpsL20 xyl-5 mtl-1 recA13] (Sambrook et al., 1989), TG1 [F' (traD36 lac $I^{\mathrm{q}} \Delta(\mathrm{lac} Z) M 15$ pro $\left.A^{+} B^{+}\right)$supE $($bsdM-mrcB) 5 thi $\Delta($ lacpro $A B)]$ (Amersham) and GM119 [F- $\mathrm{F}^{-}$dam-3 dcm-6 metB1 sup E44 galK2 galT22 lacY1 tsx-78 (thi-1 ton $A 31$ mtl-1)?] (Arraj \& Marinus, 1983). Plasmids pBR322, pUC18 and pUC19 were used for cloning and sequencing. $X$. campestris was grown at $30{ }^{\circ} \mathrm{C}$ with shaking in a medium containing $2 \%(\mathrm{w} / \mathrm{v})$ sucrose, $0.5 \%$ peptone, $0.5 \mathrm{~g} \mathrm{~K}_{2} \mathrm{HPO}_{4} \mathrm{I}^{-1}$ and $0.25 \mathrm{~g} \mathrm{MgSO}_{4} .7 \mathrm{H}_{2} \mathrm{Ol}^{-1}$ $(\mathrm{pH} 7 \cdot 0)$. E. coli cells were cultured in Luria-Bertani broth (Sambrook et al., 1989) at $30^{\circ} \mathrm{C}$ or $37^{\circ} \mathrm{C}$ with shaking.

Molecular cloning and sequencing procedures. Plasmid DNA was isolated by the alkaline extraction procedure or by $\mathrm{CsCl} /$ ethidium bromide equilibrium density gradient centrifugation (Sambrook et al., 1989). X. campestris chromosomal DNA was isolated by the method of Chesnney et al. (1979). The selected plasmids were sequenced by the dideoxy chaintermination method (Sanger et al., 1977) using double-stranded 
plasmids as templates and universal or specific oligonucleotides as primers. Southern-blot analysis was carried out as described by Sambrook $e t$ al. (1989). The DNA probe was labelled using the Polar PLEX Chemiluminescent Blotting Kit (Millipore). Competent cells for transformation were prepared by rubidium chloride treatment (Sambrook et al., 1989). To prepare the genomic libraries of $X$. campestris, the chomosomal DNA was digested with BamHI, PstI, HindIII or EcoRI and the resulting fragments were ligated to the vector pBR322 previously digested with the corresponding restriction enzyme.

Computer analysis. Nucleotide sequences were analysed using the University of Wisconsin Molecular Biology Package (WIMP) available on the VAX cluster mainframe computer system at the Biotechnology National Center (Madrid). Sequence comparisons were made against the GenBank/EMBL database and the Swissprot database, using the FASTA and TFASTA programs.

Enzyme activity assay. Pip activity was assayed by measuring the amount of $p$-nitroanilide ( $p$-NA) liberated from $p$-NA substrates $(1 \mathrm{mM})$ as described by Klein et al. (1994). One unit of enzyme activity was defined as the amount of enzyme releasing $1 \mathrm{nmol} p$-NA min ${ }^{-1}$. The protein concentration was determined by the method of Bradford (1976).

Molecular mass determination. Cell pellets of E. coli HB101(pJJ185) were resuspended in $0.1 \mathrm{M}$ Tris/ $\mathrm{HCl} \mathrm{pH} \mathrm{7.5,}$ and disrupted by sonication. The cell suspension was centrifuged at $30000 \mathrm{~g}$ for $15 \mathrm{~min}$. The clear solution $(0.1 \mathrm{ml})$ was applied to a Superose 12HR 10/30 column (Pharmacia) equilibrated and eluted with $0.1 \mathrm{M}$ Tris/ $\mathrm{HCl} \mathrm{pH} \mathrm{7.5.} \mathrm{The} \mathrm{fraction}$ showing the highest activity was used for analytical purposes. SDS-PAGE was performed as described by Laemmli (1970). Standard marker proteins were from Bio-Rad.

$\mathrm{N}$-terminal amino acid sequencing. The sample was prepared by applying the purified enzyme solution to a Prospin sample preparation cartridge containing a PVDF membrane (Immobilon, Millipore). The amino acid sequence was determined by the Edman degradation method using a pulse-liquid sequencer (model 4701; Applied Biosystems).

\section{RESULTS AND DISCUSSION}

\section{Isolation and subcloning of the pip gene}

The pip gene of $X$. campestris pv. citri IFO 3835 was cloned during the course of a screening programme developed to isolate the ama gene encoding the ampicillin acylase ( $\boldsymbol{\alpha}$-amino acid ester hydrolase, ampicillin amidase) of this strain (Kato et al., 1980a). The selection procedure was developed according to a method originally designed to isolate penicillin-acylase-coding genes (García \& Buesa, 1986). This method is based upon the auxotrophic complementation of an E. coli leuB mutant using a minimal medium containing phenylacetyl-L-leucine as the sole source of L-leucine. To clone ama genes, we replaced phenylacetyl-L-leucine by D-alanyl-L-leucine in the selective medium, since it has been reported that ampicillin acylase has a broad substrate specificity, being able to hydrolyse different amides and esters of $\mathrm{D}$-amino acids (Kato et al., 1980b).

Among several thousand transformants of E. coli HB101 (which is a leuB strain) screened from the genomic libraries of $X$. campestris IFO 3835 constructed in pBR322, only one, isolated from a PstI library, was able to grow in minimal medium using $\mathrm{D}$-alanyl-L-leucine as a source of $\mathrm{L}$ leucine. Since this transformant was unable to grow in the absence of L-leucine we concluded that it was not a LeuB ${ }^{+}$ revertant and discarded the possibility that we had cloned the leuB gene of $X$. campestris. The isolated plasmid pJJ10 is a pBR322 derivative carrying a $2 \cdot 8 \mathrm{~kb}$ Pst $\mathrm{I}$ insert (Fig. 1). Southern-blot analyses demonstrated that the cloned fragment was present in the chromosome of $X$. campestris (Fig. 2). Under the same experimental conditions, no hybridization was detected with the E. coli chromosome. When competent cells of E. coli HB101 were transformed with pJJ10, all the transformants were able to grow in minimal medium containing D-alanyl-L-leucine, suggesting that this plasmid encodes a peptidase that might correspond to the ampicillin acylase activity. Surprisingly, cell extracts prepared from E. coli HB101(pJJ10) were unable to hydrolyse ampicillin (data not shown), suggesting either that we had cloned a different gene or that the ampicillin acylase activity produced by this clone was not detected by the current assay used. Moreover, the recombinant was unable to grow in minimal medium containing D-leucyl-L-leucine as a source of L-leucine, indicating a certain specificity for the hydrolysis of the dipeptide.

\section{Nucleotide sequence}

To determine the location of the gene encoding the peptidase, the Pst $\mathrm{I}$ fragment of $\mathrm{pJJ} 10$ was digested with different restriction enzymes and subcloned into vectors pUC18 or pUC19, resulting in the plasmids pJJ182, pJJ191, pJJ192, pJJ193, pJJ194 and pJJ195 (Fig. 1). Of these plasmids, only pJJ191 and pJJ195 conferred upon E. coli HB101 the ability to grow in the presence of $\mathrm{D}-$ alanyl-L-leucine (Fig. 1). Thereafter, plasmid pJJ195 was used to determine the nucleotide sequence of the cloned PstI-ClaI fragment (Fig. 3). The sequence revealed the presence of two major overlapping and divergent open reading frames, named ORF1 and ORF2, and a truncated ORF3 (Fig. 3).

Two in-phase ATG codons were found at the $5^{\prime}$ terminus of ORF1, but only one was preceded by a sequence (AGGA) resembling a ribosome-binding site (RBS) located at an appropriate distance (Fig. 3). This ORF1 encodes a protein of 312 amino acids (35126 Da) with a calculated $\mathrm{pI}$ of 6.4 . Two putative promoter regions showing a distance of $21 \mathrm{bp}$ between the respective -35 and -10 boxes and a low similarity with the $E$. coli $\sigma^{70}$ consensus promoter were detected upstream of this ORF1 (Fig. 3). Although a distance of $21 \mathrm{bp}$ between boxes and a low consensus similarity have been observed in known promoters (Hawley \& McClure, 1983), the precise transcription start site remains to be elucidated. Furthermore, there were no palindromic sequences suggestive of a terminator structure downstream of the TAA stop codon of ORF1. A database search showed that the putative protein encoded by ORF1 was highly similar ( $47 \%$ identity, $67 \%$ similarity) to the Pip enzyme from Neisseria gonorrboeae. This protein also shows a limited similarity with other Pips and hydrolases of aromatic compounds, e.g. Pip from Aeromonas sobria (24\% identity, 54\% 


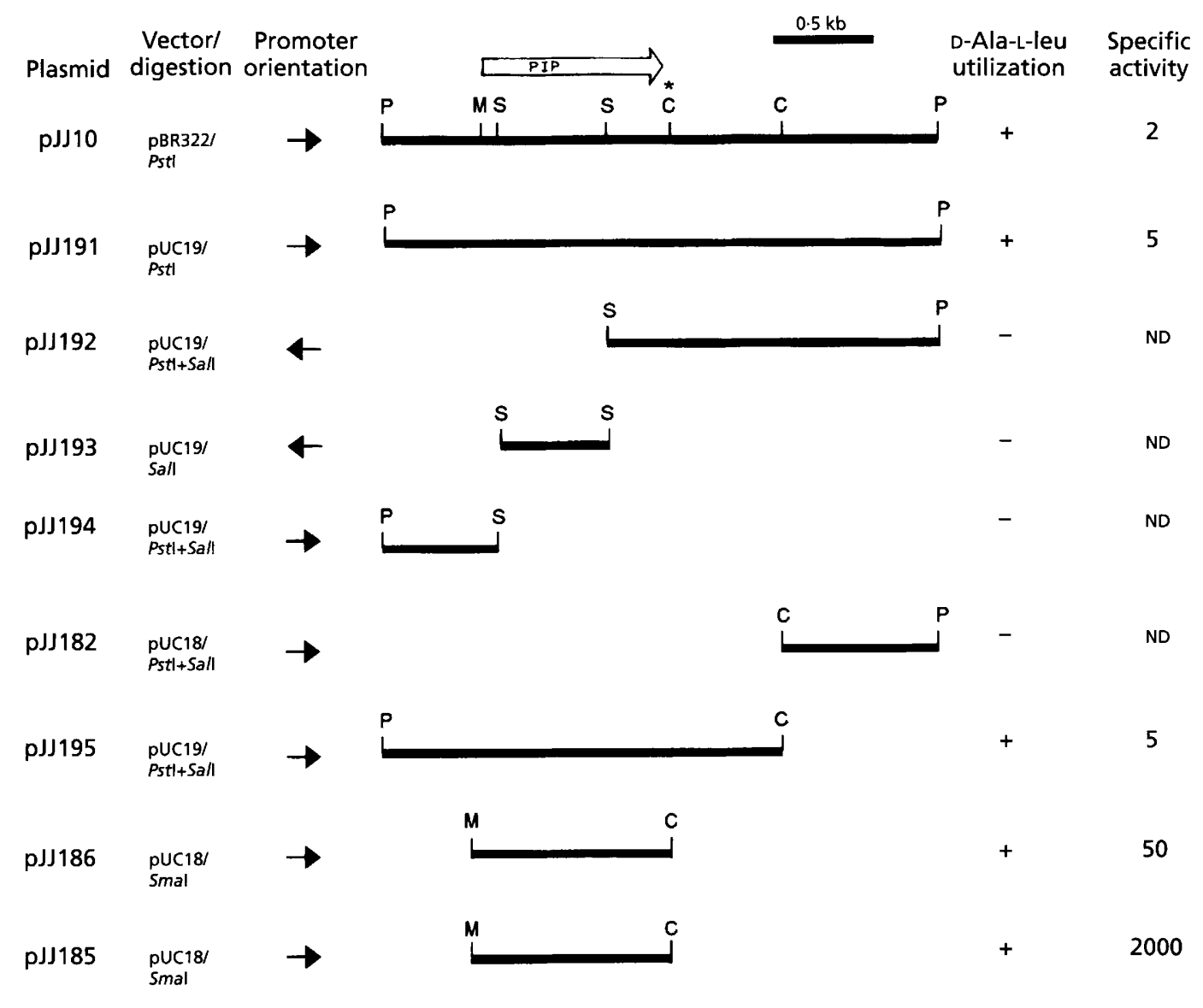

Fig. 1. Restriction map of the pip gene from $X$. campestris. Abbreviations: $C$, Clal; $C^{\star}$, methylated Clal site; M, Mael; $P$, Pstl; S, Sall. Enzyme specific activity [U (mg protein $)^{-1}$ ] was determined in extracts of the $E$. coli HB101 recombinants using L-prolyl-p-NA as substrate (ND, not detected). In pJJ185 the pip gene is in-frame with lacZ on the vector.

similarity), Pip from Lactobacillus delbrueckii (24\% identity, $51 \%$ similarity), Pip from Bacillus coagulans ( $24 \%$ identity, $47 \%$ similarity), 2-hydroxy-6-oxo-6-phenylhexa2,4-dienoate hydrolase from Pseudomonas putida $(26 \%$ identity, $49 \%$ similarity), 2-hydroxy-6-oxohepta-2,4dienoate hydrolase from $P$. putida (25\% identity, $49 \%$ similarity) and 2-hydroxymuconic semialdehyde hydrolase from P. putida (23\% identity, $46 \%$ similarity). This similarity is especially marked in the regions surrounding the postulated catalytic amino acids (Díaz \& Timmis, 1995; Kitazono et al., 1994b) (Fig. 4).

ORF2 and ORF3 did not have any RBS-like sequences preceding the respective start codons, and their deduced amino acid sequences did not show any significant similarity with other proteins contained in the databanks.

\section{Expression of the cloned gene and identification of its product}

The findings reported above strongly suggested that we had cloned the pip gene of $X$. campestris pv. citri. To confirm this, cell extracts of $E$. coli cells harbouring the subcloned fragments were analysed for the presence of a Pip-like activity. A Pip activity was only detected in the recombinants able to grow in the presence of D-alanyl-Lleucine, carrying the complete pip gene (Fig. 1). This result demonstrated that the hydrolytic activity was not due to the Pip of E. coli and strongly suggested that it can be ascribed to the cloned gene.

Since the production of Pip in E. coli HB101(pJJ195) was very low and the pip expression was not inducible by IPTG (data not shown) we assumed that the gene was transcribed under the control of a weak promoter contained in the cloned fragment. To express the pip gene under the control of an E. coli promoter we isolated the ORF1 using the restriction sites MaeI and ClaI located in its noncoding flanking regions. To allow the digestion of the methylated ClaI site, pJJ195 was isolated from E. coli GM119. Thereafter, the $1 \mathrm{~kb} \mathrm{MaeI-ClaI} \mathrm{fragment} \mathrm{carrying}$ the pip gene was made blunt-ended, purified and ligated to SmaI-digested pUC18. This construction generates a stop codon just at the $S m a \mathrm{I}-M a e \mathrm{I}$ junction that avoids the creation of an in-frame fusion with the lac $Z$ gene of pUC18. One of the resulting plasmids, named pJJ186 (Fig. 1) was sequenced to confirm the accuracy of the construction. Interestingly, among the isolated E. coli HB101 recombinant clones, two transformants displayed a very high Pip activity on L-prolyl-p-NA measured in cell 


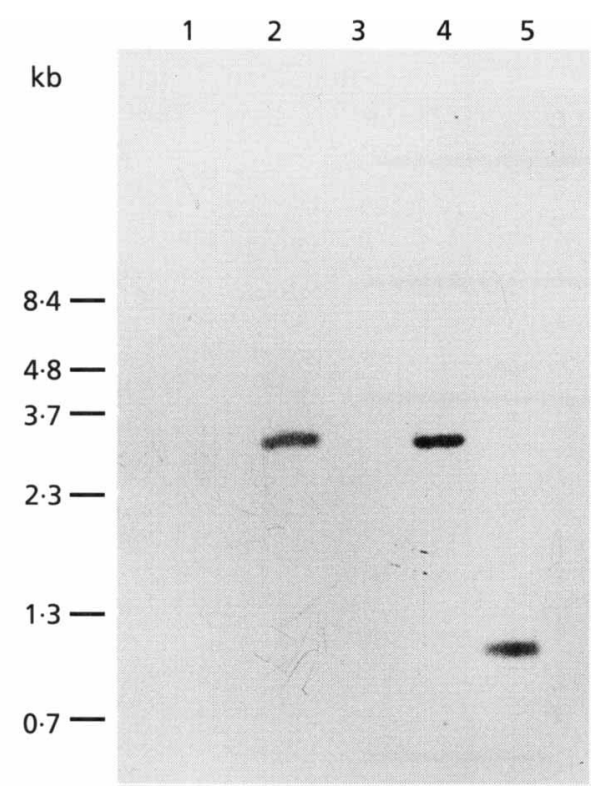

Fig. 2. Southern hybridization of chromosomal DNA from $X$. campestris. The filter was probed using the $2.8 \mathrm{~kb}$ Pstl fragment from pJJ10. Lane 1, E. coli HB101 DNA digested with Pstli lane $2, X$. campestris DNA digested with Pstl; lane $3, \lambda$ DNA digested with BstEll; lane 4, 2.8 kb Pstl fragment from pJJ10; lane 5, $1.0 \mathrm{~kb}$ Mael-Clal fragment from pJJ195.

extracts. These clones harboured a similar, but not identical, plasmid, named pJJ185, which had lost a nucleotide in the SmaI-MaeI junction, producing an inframe fusion with the lac $Z$ gene of the vector. Cells harbouring pJJ185 hyperproduced a $37 \mathrm{kDa}$ protein that corresponds to the expected size of the fusion protein (Fig. 5). Due to the high amount of Pip produced by $E$. coli $\mathrm{HB} 101$ (pJJ185) the enzyme can be purified in one step by gel filtration (Fig. 5). The N-terminal amino acid sequence, Thr-Met-Ile-Thr-Asn, found in the purified protein perfectly matched the predicted $\beta$-galactosidase Pip fusion. The production of the fusion protein was inducible by IP'TG in E. coli TG1 and constitutive in HB101, indicating that pip expression is under the control of the lac promoter (Fig. 5). The Pip activity produced by clones harbouring PJJ185 was 40-fold higher than that produced by cells carrying pJJ186 and 400-fold higher than that detected in $X$. campestris (Fig. 1). The high production of the Pip fusion can probably be ascribed to a higher initiation efficiency (MacCarthy \& Brimacombe, 1994). Interestingly, a similar result was observed with the prolyl aminopeptidase from Aeromonas sobria, where a fusion protein with the $\beta$-galactosidase produced a 19-fold increase in enzyme activity (Kitazono et al., 1994b).

\section{Characterization of the Pip activity}

Pip prepared from E. coli TG1(pJJ186) behaved in gel filtration as a protein with an apparent molecular mass of $120 \mathrm{kDa}$, suggesting that the active enzyme might be a tetramer, as already suggested for the Pip of Aeromonas sobria (Kitazono et al., 1994b) or apricot seeds (Ninomiya orr $\Rightarrow$

1 AGCAGGGCGATCTTCGCTACGAACCGGCCAGTGCGCTGGCCTCCGGCAGCGACGGGCTGG 60 61 ACGATATCCGCCTGATCGTGGCCGATGCGCCTGCCGATCTGCTGCCGGGCGGCTGGTTGC 120 121 TGCTGCAACATGGCTGGGACCAGGGGGCAGCGGTGGCCGAACTGCTGGTTGCCCCCGGTT 180 181 TCCGCTGCGGTGGCCACGCATCAGGATCTGGAGCAGCGCGATCGGGTEACCTTGGGGCGC 240 ESTOP ORT2

241 TGGTTGCCAGCTGCGGGCCAGGGCGGCTGAGCAACTGCCCGCGCGCTATTGTCGGGAGAC 300 301 GAGGGCCGGGCGTTCCGAAGCGGAGTACGTGCGTTCGATAGAGCGGTTGCGGCATCGAGT 360 361 GCGCTCGCCCGCCGGTAAGCGCAGAAGGTTGGGTGCGCTCTTCAGGGCTTGGCCCATCAC 420 421 GGCGAACTCTTCTCTTCGAATCGCATGGCGTTGCCCGTGTGCGTGCGCAGCTGCCGATAC 480 $\begin{array}{ll}\text { MaeI } & -10 \\ \text { ORT1 (PIP) } \Rightarrow\end{array}$ 481 ACTAGCGGTTTCCCGCAGGACCGACGCATECGCACGCTCTATCCCGAGATCACGCCCTAC 540

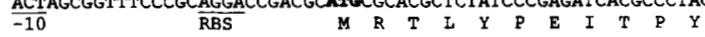
541 CAGCAGGGCAGCCTGAAGGTCGACGATCGCCATACGCTGTACTTCGAGCAGTGCGGCAAT 600 $\begin{array}{llllllllllllllllllll}Q & Q & G & S & \text { I } & K & \text { V } & \text { D } & \text { D } & \text { R } & \text { H } & \text { T } & \text { L } & \text { Y } & \text { F } & \text { E } & Q & \text { C } & G & N\end{array}$ 601 CCGCACGGCAAGCCGGTGGTGATGTTGCATGGCGGCCCCGGCGGCGGATGCAACGACAAG 660 $\begin{array}{lllllllllllllllllll}P & H & G & \text { G } & \text { V } & \text { V } & M & \text { I } & H & G & G & P & G & G & G & C & N & D & K\end{array}$

661 ATGCGGCGCTTCCACGACCCGGCCAAGTACCGCATCGTGCTGTTCGATCAGCGCGGTTCC 720

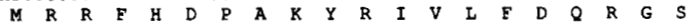

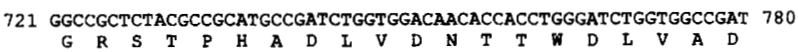

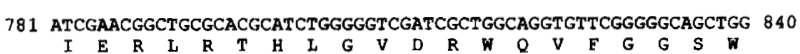
841 GGATCCACGCTGGCGCTGGCCTACGCGGCAGACCCATCCGCAGCAGGTCACCAGCTGGTG 900

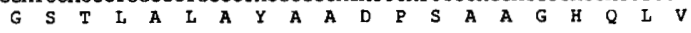
901 CTGCGCGGTATTTTCCTGCTGCGTCGCTTCGAACTCGAATGGTTCTACCAGGAAGGTGCC 960

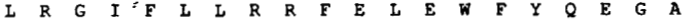
961 AGCCGCCTGTTCCCGGATGCGTGGGAGCATTACCTCAACGCGATTCCGCCGGTGGAACGC 1020 $\begin{array}{lllllllllllllllllllll}S & R & L & F & P & D & A & \text { W } & E & H & Y & \text { L } & \text { N } & \text { A } & \text { I } & \text { P } & \text { P } & \text { V } & \text { E } & R\end{array}$

1021 GCCGACTTGATGTCTGCATTCCATCGCCGTCTCACCAGCGATGACGAGGCCACGCGTCTG 1080 $\begin{array}{llllllllllllllllllll}\text { A } & \text { D } & \text { L } & \text { M } & \text { S } & \text { A } & \text { F } & \text { H } & \text { R } & \text { R } & \text { L } & \text { T } & \text { S } & \text { D } & \text { D } & \text { E } & \text { A } & \text { T } & \text { R } & \text { I }\end{array}$

1081 GCTGCGGCCAAAGCCTGGAGCGTGTGGGAAGGCGCCACCAGCTTCCTGCATGTCGACGAG 1140 1141 GACTTCGTCACCGGACATGAAGACGCGCACTTTGCCCTGGCGTTCGCACGCATCGAAAAC 1200

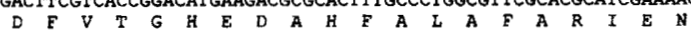
€OAr2

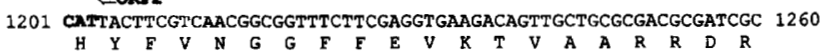
1261 ATTGCCGACATTCCCGGCGTGATCGTGCACGGCCGCTACGATGTGGTGTGCCCGCTGCAA 1320 $\begin{array}{lllllllllllllllllll}I & A & D & I & P & G & V & I & V & H & G & R & Y & D & V & V & C & P & I\end{array}$

1321 AGCGCGTGGGACCTGCACAAGGCGTGGCCCGAACGGCAGTTGCAGATCAGCCCGGATCG 1380 $S$ S A W

1381 GGGCACTCAGCGTTCGAACCGGAAAACGTCGATGCCTTGGTGCGTGCCACCGACGGGTTT 1440 $G$ H

1441 GCGXAACGGAGTGCATGCGCATCGATCAGAGTTCGCTTTGGTCGATCGGCATGATCACTC 1500 1502. TGCCCGGACGCGGTGAGGTGCGATGACATACGCATGACGTGTCGGAGCGCGCTTACGCGG 1560

Fig. 3. Nucleotide sequence of the pip gene from $X$. campestris pv. citri and its deduced amino acid sequence. The putative RBS sequence (AGGA) and sequences that resemble the strong promoters of $E$. coli are underlined. The initiation and stop codon are shown in bold letters. Arrows indicate the direction of transcription of the ORFs.

et al., 1982), but we cannot completely rule out the possibility that it might be a trimer having a non-globular shape like the Pip enzyme from Lactobacillus delbrueckii subsp. bulgaricus (Gilbert et al., 1994). The optimum pH for the enzyme was 7.5 and the maximum activity was observed at $40^{\circ} \mathrm{C}$. The fusion protein prepared from $E$. coli TG1(pJJ185) also behaved in gel filtration as a multimer showing an apparent molecular mass of $150 \mathrm{kDa}$. Recently, this fusion protein has been crystallized and the preliminary diffraction data suggest that its three-dimensional structure can probably be solved soon (F. J. Medrano, personal communication).

The results shown in Table 1 indicate that the Pip of $X$. campestris hydrolysed L-prolyl-p-NA with the highest 
(1) 99 LGVDRW-QVFGG8WGSTLALAYAADPSAAGHQLVLRG 134

(2) 96 LGIGKW-IVFGG8WGSTLSLAYAQTHPERVKLIVIRG 131

(3) 90 LNLDEV-HILGHSWGTTLAAAY-CLTKPSGVKSVIFS 124

(4) 95 LGLDQI-HLLGQSWGGMLALIYLCDYQPKGVKSIILS 130

(5) 134 LSPDHPWSLLGQSFGGFCSLTYLSLFPDSLHEVYLTG 170

(6) 94 LELDRV-DLVGNSFGGALSLAFAIRFPHRVRRLVLMG 129

(7) 95 LGIQQG-DIVGN8FGGGLALALAIRHPERVRRLVLMG 130

(8) 101 LGIDRA-HLVGNSMGGATALNFAIEYPDRIGKLILMG 136

(9) 99 MGLHNT-TVIGHSMGSMTAGVLAS IHPDKVSRLVLIS 134
256 PGVIVHGRYDVVCPLQSAWDLHKAWPERQLQISPASGHSA-FEPENVDALVR 306 251 PTVIVQGRYDLCT PMQSAVELSKAFPEAELRVVQA-GHCAAFDPPLADALVQ 301 231 PSLYTCGRFDEAT PETTEY-YSSIT PKSKFHVFEKSARMP-YIEEPEEYLAV 279 236 PALITSGTDDLCT PLVAKS-MYDHLPNARWEIFAGCGIMP-FVQENAKYQEI 284 367 PVACAVYAEDMYVEFDYSRETLKGLSNSRAWITNEYEHNGLRVDGEQILDRL 417 217 ETLILHGRDDRVI PLETSLRLNOLIEPSOLHVFGRCGEWV-OIEONRGFIRI 266 218 ETLVIHGREDRI I PLQASLTLAQWIPNAQLHVFGQCGHWT-QIEHAEREARI 267 228 KTFITWGRDDRFVPLDHGLKLLWNIDDARLHVESKCGHWA-QWEHADEFNRI 277 216 KTLILWGNONOPMTESMONDIRAALPKAKFIOYNGFGBSM-FWEDPEMVAKD 265

Fig. 4. Alignment of the regions surrounding the catalytic amino acids of several enzymes. (1), Pip from $X$. campestris (this work); (2), Pip from N. gonorrhoeae (Albertson \& Koomey, 1993); (3), Pip from B. coagulans (Kitazono et al., 1992); (4), Pip from L. delbrueckii (Klein et al., 1994); (5), Pip from A. sobria (Kitazono et al., 1994a); (6), 2-hydroxy-6-oxohepta2,4-dienoate hydrolase from $P$. putida (Menn et al., 1991); (7), 2-hydroxymuconic semialdehyde hydrolase from $P$. putida (Horn et al., 1991); (8), 2-hydroxy-6-oxo-6-phenylhexa-2,4-dienoate hydrolase from P. putida (Hayase et al., 1990); (9), atropinesterase from P. putida (Hessing, 1983). A, B and C indicate the regions surrounding the postulated catalytic amino acids that are shown in bold letters.

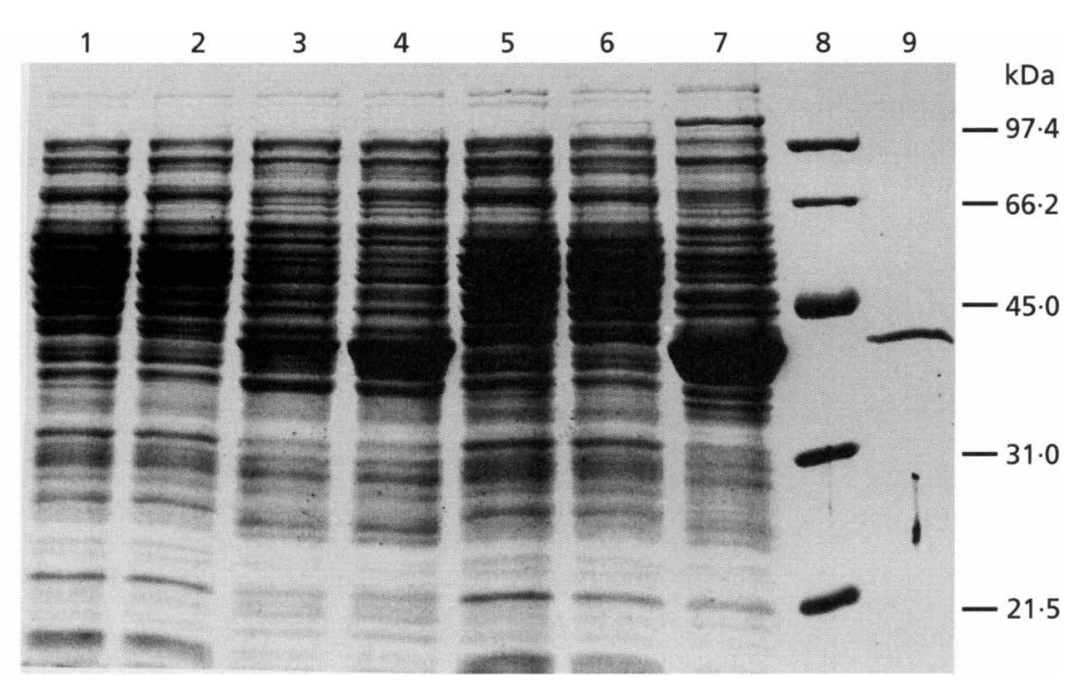

Fig. 5. SDS-PAGE of bacterial lysates of $E$. coli transformants. Each lysate and the purified enzyme were electrophoresed in a $10 \%(\mathrm{w} / \mathrm{v})$ polyacrylamide gel and stained with Coomassie Brilliant Blue. Lane 1, TG1(pUC18); lane 2, TG1(pUC18) + $1 \mathrm{mM}$ IPTG; lane 3, TG1(pJJ185); lane 4, TG1(pJ 185) + $1 \mathrm{mM}$ IPTG; lane 5 , TG1(pJJ186); lane 6, TG1(pJJ186) + $1 \mathrm{mM}$ IPTG; lane 7, HB101(pJJ185); lane 8, molecular mass standards; lane 9, LacZ-Pip fusion protein purified by gel filtration.
Table 1. Hydrolysis of various substrates by the Pip from $X$. campestris

\begin{tabular}{|lcrrr|}
\hline Substrate & \multicolumn{4}{c|}{ Activity [U (mg protein) $\left.)^{-1}\right]^{*}$} \\
\cline { 2 - 4 } & \multicolumn{2}{c}{ E. coli HB101 extracts } & $\begin{array}{c}\text { Purified } \\
\text { fusion }\end{array}$ \\
& (pUC18) & (pJJ186) & (pJJ185) & \\
\hline L-Prolyl- $p$-NA & ND & 47 & 2251 & 7484 \\
L-Alanyl- $p$-NA & 80 & 117 & 1948 & 6237 \\
D-Alanyl- $p$-NA & ND & 1 & 20 & 66 \\
\hline
\end{tabular}

* The values represent the means of three independent experiments, performed with cell extracts of E. coli HB101 recombinants carrying plasmids pUC18 (control), pJJ186 (wild-type Pip) or pJJ185 (Pip fusion) or the purified Pip fusion. ND, Not detected. None of the four preparations showed detectable activity against L-phenylalanyl- $p$-NA, D-phenylalanyl- $p$-NA, L-leucyl- $p$-NA or D-leucyl- $p$ NA.

efficiency ( $100 \%$ activity), but it was also able to hydrolyse L-alanyl- $p$-NA (80\% activity) and $\mathrm{D}$-alanyl- $p$-NA ( $1 \%$ activity). Interestingly, L-alanyl- $p$-NA was not efficiently cleaved by the Pip of two subspecies of $L$. delbrueckit (Gilbert et al., 1994; Klein et al., 1994). The Pip from apricot seed hydrolyses glycyl- $\beta$-naphthylamide at a low efficiency but not the L-alanine derivative (Ninomiya et al., 1982). The finding that D-alanyl- $p$-NA can be hydrolysed at low efficiency by the Pip of $X$. campestris probably explains why the D-alanyl-L-leucine dipeptide is used in vivo by E. coli HB101(pJJ10) as a source of L-leucine by the pip recombinants, and fits with the observation that this dipeptide was hydrolysed in vitro at a low but detectable rate (data not shown). In contrast, the dipeptide D-leucylL-leucine cannot be used in vivo by E. coli HB101(pJ J10) as a source of L-leucine and the D-leucyl-p-NA cannot be hydrolysed in vitro.

\section{Concluding remarks}

The very low endogenous Pip activity of $E$. coli has allowed its use as a host for cloning and expressing the pip gene from $X$. campestris pv. citri. The substrate specificity of this novel Pip provides a formal explanation for the fortuitous isolation of its encoding gene using a selection method that was initially developed to clone a different 
family of genes. The enzyme was produced as a soluble protein in E. coli and $X$. campestris. The Pip activity was not detected in the culture medium and it is not produced as a preprotein. The Pip characterized in this work is not the proline-specific endopeptidase previously described in Xanthomonas sp. (Szwajcer-Dey et al., 1992), since this endopeptidase is a monomer with a molecular mass of 75 $\mathrm{kDa}$ and has a different substrate specificity.

Finally, it is worth noting that the Pip has been suggested to be a virulence factor of some human pathogenic bacteria such as Eikenella corrodens (Allaker et al., 1994) and $N$. gonorrboeae (Albertson \& Koomey 1993). Hence, based on the observation that protease-deficient mutants of $X$. campestris pathovars showed a reduced virulence (Dow $e t$ al., 1993), it is possible that this enzyme might influence the capacity of $X$. campestris to cause plant damage.

\section{ACKNOWLEDGEMENTS}

We are grateful to F. J. Medrano, P. García, R. López and E. García for valuable suggestions and discussions. The technical assitance of M. Carrasco and E. Cano is gratefully acknowledged. We also wish to thank A. Hurtado for the artwork.

\section{REFERENCES}

Albertson, N. H., \& Koomey, M. (1993). Molecular cloning and characterization of a proline iminopeptidase gene from Neisseria gonorrboeae. Mol Microbiol 9, 1203-1211.

Allaker, R. P., Young, K. A. \& Hardie, J. M. (1994). Production of hydrolytic enzymes by oral isolates of Eikenella corrodens. FEMS Microbiol Lett 123, 69-74.

Atlan, D., Gilbert, C., Blanc, B. \& Portalier, R. (1994). Cloning, sequencing and characterization of the pepIP gene encoding a proline iminopeptidase from Lactobacillus delbrueckii subsp. bulgaricus CNRZ 397. Microbiology 140, 527-535.

Arraj, J. A. \& Marinus, M.-G. (1983). Phenotypic reversal in dam mutants of Escherichia coli K-12 by recombinant plasmid containing the dam ${ }^{+}$gene. J Bacteriol 153, 562-565.

Bradford, M. M. (1976). A rapid and sensitive method for the quantitation of microgram quantities of protein utilizing the principle of protein-dye binding. Anal Biochem 72, 248-254.

Chesnney, R. H., Scott, J. R. \& Vapnek, O. (1979). Integration of the plasmid prophages $\mathrm{P} 1$ and $\mathrm{P} 7$ into the chromosome of Escherichia coli. J Mol Biol 130, 161-173.

Díaz, E. \& Timmis, K. N. (1995). Identification of functional residues in a 2-hydroxymuconic semialdehyde hydrolase. J. Biol Chem 270, $1-9$.

Dow, J. M., Fan, M. J., Newman, M.-A. \& Daniels, M. J. (1993). Differential expression of conserved protease genes in cruciferattacking pathovars of Xanthomonas campestris. Appl Environ Microbiol 59, 3996-4003.

Ehrenfreund, P., Mollay, C. \& Kreil, G. (1992). Purification and properties of an iminopeptidase from culture media of Streptomyces plicatus. Biochem Biopbys Res Commun 184, 1250-1255.

García, J. L. \& Buesa, J. M. (1986). An improved method to clone penicillin acylase genes: cloning and expression in Escherichia coli of penicillin $\mathrm{G}$ acylase from Kluyvera citropbila. J Biotecbnol 3, 187-195. Gilbert, C., Atlan, D., Blanc, B. \& Portalier, R. (1994). Proline iminopeptidase from Lactobacillus delbrueckii subsp. bulgaricus CNRZ 397: purification and characterization. Microbiology 140, 537-542.
Hawley, D. K. \& McClure, W. R. (1983). Compilation and analysis of Escherichia coli promoter DNA sequences. Nucleic Acids Res 11, 2237-2255.

Hayase, N., Taira, K. \& Furukawa, K. (1990). Pseudomonas putida $\mathrm{KF} 715 b p h A B C D$ operon encoding biphenyl and polychlorinated biphenyl degradation: cloning, analysis and expression in soil bacteria. J Bacteriol 172, 1160-1164.

Hessing, J. G. M. (1983). The primary structure of atropinesterase from Pseudomas putida. PhD thesis, University of Leiden.

Hiraoka, B. \& Harada, M. (1991). Use of L-prolyl-leucylglycinamide (MIF-1) for the high-performance liquid chromatographic determination of proline iminopeptidase activity in rat liver. $J$ Chromatogr 563, 142-146.

Horn, J. M., Harayama, S. \& Timmis, K. N. (1991). DNA sequence determination of the TOL plasmid ( $\mathrm{pWW} 0$ ) xy/IGFJ genes of Pseudomonas putida: implications for the evolution of aromatic catabolism. Mol Microbiol 5, 2459-2474.

Kato, K., Kawahara, K., Takahashi, T. \& Kakinum, A. (1980a). Purification of $\alpha$-amino acid ester hydrolase from Xanthomonas citri. Agric Biol Chem 44, 1069-1074.

Kato, K., Kawahara, K., Takahashi, T. \& Kakinum, A. (1980b). Substrate specificity of $\alpha$-amino acid ester hydrolase from Xanthomonas citri. Agric Biol Chem 44, 1075-1081.

Kitazono, A., Yoshimoto, T. \& Tsuru, D. (1992). Cloning, sequencing and high expression of the proline iminopeptidase gene from Bacillus coagulans. J Bacteriol 174, 7919-7925.

Kitazono, A., Kitano, A.,Tsuru, D. \& Yoshimoto, T. (1994a). Isolation and characterization of the prolyl aminopeptidase gene (pap) from Aeromonas sobria: comparison with the Bacillus coagulans enzyme. $J$ Biochem 116, 818-825.

Kitazono, A., Ito, K. \& Yoshimoto, T. (1994b). Prolyl aminopeptidase is not a sulfhydryl enzyme: identification of the active serine residue by site-directed mutagenesis. J Biochem 116, 943-945.

Klein, J. R., Schmidt, U. \& Plapp, R. (1994). Cloning, heterologous expression, and sequencing of a novel proline iminopeptidase gene, pepI, from Lactobacillus delbrueckii subsp. lactis DSM 7290. Microbialogy 140, 1133-1139.

Laemmli, U. K. (1970). Cleavage of structural proteins during the assembly of the head of bacteriophage T4. Nature 227, 680-685.

MacCarthy, J. E. G. \& Brimacombe, R. (1994). Prokaryotic translation: the interactive pathway leading to initiation. Trends Genet 10, 402-407.

Menn, F. M., Gerben, J. Z. \& Gibson, D. T. (1991). Location and sequence of the todF gene encoding 2-hydroxy-6-oxohepa-2,4dienoate hydrolase in Pseudomonas putida. Gene 104, 91-94.

Ninomiya, K., Kawatani, K., Tanaka, S., Kawata, S. \& Makisumi, S. (1982). Purification and properties of a proline iminopeptidase from apricot seeds. $J$ Biochem 92, 413-421.

Sambrook, J., Fritsch, E. J. \& Maniatis, T. (1989). Molecular Cloning: a Laboratory Manual. Cold Spring Harbor, NY: Coid Spring Harbor Laboratory,

Sanger, F., Nicklen, S. \& Coulson, A. R. (1977). DNA sequencing with chain-terminating inhibitors. Proc Natl Acad Sci US A 74 5463-5467.

Sarid, S., Berger, A. \& Katchalski, E. (1959). Proline iminopeptidase. J Biol Chem 234, 1740-1744

Szwajcer-Dey, E., Rasmussen, J., Meldal, M. \& Breddman, K. (1992). Proline-specific endopeptidases from microbial sources: isolation of an enzyme from Xanthomonas sp. $J$ Bacteriol 174, 2454-2459.

Verniere, C., Provost, O., Civerolo, E. L., Gambin, O., Jacquemoud- 
Collet, J. P. \& Luisette, J. (1993). Evaluation of the biolog substrate utilization system to identify and assess metabolic variation among strains of Xanthomonas campestris pv. citri. Appl Environ Microbiol 59, 243-249.

Yoshimoto, T., Saeki, T. \& Tsuru, D. (1983). Proline iminopeptidase from Bacillus megaterium: purification and characterization. J Biochem 93, 469-477.

Received 16 April 1996; revised 27 June 1996; accepted 8 July 1996. 